Salmerón Pérez, H., Gutiérrez-Braojos, C., Rodríguez Fernández, S. (2017). The relationship of gender, time orientation, and achieving self-regulated learning. Revista de Investigación Educativa, 35(2), 353-369

DOI: http://dx.doi.org/10.6018/rie.35.2.273141

\title{
The relationship of gender, time orientation, and achieving self-regulated learning
}

\section{La relación entre el género, la orientación temporal, y el logro en el aprendizaje autorregulado.}

\author{
Honorio Salmerón Pérez, Calixto Gutiérrez-Braojos* and Sonia Rodríguez Fernández* \\ *Universidad de Granada
}

\begin{abstract}
The present study has three objectives: $i$ ) to test a theoretical model of academic achievement modulated by self-regulated learning; ii) to analyze significant differences between self-regulated learning means and time patterns depending on the gender of the participants; and iii) to identify self-regulated learning profiles toward academic achievement based on gender. The data were obtained from a sample of 192 university students in education degrees who were administered three instruments: a Future Time Orientation subscale by Zimbardo and Boyd, (1999); the $2 \times 2$ Achievement Goals Scale by Elliot and McGregor (2001), and a Learning Regulation subscale by Vermunt (1998). In addition, they answered a question about their mean grade point average up to that point in the academic degree studied. The results indicate a significant and positive relationship between the future time orientation, approach goals, and external regulation strategies. Significantly higher scores are observed in women than in men on key academic performance variables, although the effect size was not large. The gender differences are exclusively quantitative. In both groups, the characteristics of the learner profiles are somewhat similar, with no important differences observed for the gender condition. In general, avoidance goals and external regulation strategies can lead to success in academic achievement, as long as they are accompanied by a future orientation, internal regulation, and approach goals.
\end{abstract}

Key words: time orientation, achievement goals, gender, self-regulated learning.

Correspondence: Honorio Salmerón Pérez, honorio@ugr.es, Departamento de Métodos de Investigación y Diagnóstico en Educación. Facultad de Ciencias de la Educación, Universidad de Granada. 


\section{Resumen}

El presente estudio acomete tres objetivos: i) testar un modelo teórico del logro académico modulado por el aprendizaje autorregulado; ii) analizar diferencias significativas entre las medias del aprendizaje autorregulado y los patrones temporales según el sexo de los participantes y iii) identificar perfiles de aprendizaje autorregulado hacia el logro académico en función del sexo. La muestra productora de datos la constituyen 192 estudiantes universitarios de carreras de educación, a los que se administraron tres instrumentos: una subescala de Orientación Temporal Futura de Zimbardo y Boyd, (1999); la Escala de Metas de Logro $2 \times 2$ de Elliot y McGregor (2001) y una subescala de Regulación del Aprendizaje de Vermunt (1998), además, una pregunta para conocer su calificación media hasta el momento en el grado académico que realizan. Los resultados indican una relación significativa y positiva entre la orientación temporal futura, las metas por aproximación, y las estrategias de regulación externa. Se observa en las mujeres puntuaciones significativamente superiores a las de los hombres en variables que son clave en el logro académico como el aprendizaje autorregulado, aunque el tamaño del efecto no fue grande. Las diferencias por sexo son exclusivamente cuantitativas. En ambos grupos las características de los perfiles de aprendices son ligeramente similares, no observándose diferencias notables por la condición de sexo. En general, se observa que las metas por evitación y las estrategias de regulación externa, pueden conducir al éxito en el logro académico siempre que estén acompañadas de orientación hacia el futuro, regulación interna, y metas por aproximación.

Palabras clave: orientación temporal; metas de logro; género, aprendizaje autorregulado.

\section{Introduction}

Since the 1950s, the time perspective has led to numerous studies in the fields of psychology and education. Although the accumulated knowledge about the time perception is based on quite varied results, two closely linked time concepts can be differentiated (Holman \& Silver, 1998): on the one hand, the time perspective, characterized by the cognitive distance of the goals along with other properties such as their degree of coherence, number, affectivity, or continuity; on the other, the time orientation, which would refer to each person's differential tendency to be focused on the past, present, or future, and where our conception of it lies.

The time orientation is conceived as a process lying at the origin of individual and social behavior that is often unconscious and makes it possible to decompose and organize the continuous flow of behavior into different time frames, giving it meaning and coherence (Zimbardo \& Boyd, 1999). This psychological time construction arises from the cognitive processes that allow the differentiation between the past, present, and future, and it has a strong influence on behavior. In the educational field, the future time perspective has been highlighted as allowing people to set goals and regulate their behavior to reach them (Díaz-Morales, 2006; Gutiérrez-Braojos, Salmerón-Pérez \& Muñoz-Cantero, 2014; Roberts, 2002; Suddendorf \& Corballis, 1997). 


\section{Future time perspective and self-regulated learning}

The time perspective in decision-making, as a construct, does not have one set meaning. Its influence on decision-making has been analyzed from studies of the personality sensitive to change (Bouffard, Bastin \& Lapierre, 1994; González \& Daura, 2012); studies on motivation and behavior (Thiebaut, 1998; Husman \& Lens, 1999; Simmons, Dewite \& Lens, 2000; Peetsma, 2000); or as a social-cognitive pattern for action, acquired through experience (James, 1890) that, when broken down into selected time spaces, offers guidelines for self-regulating the present (Lewin, 1942) and anticipating the future (Fraisse, 1967).We can consider the time perspective to be a complex and multifactorial motivational-cognitive construct (Lens, 1986; Trommsdorff, 1983; Yonge, 1974; Gjesme, 1983; Daltrey \& Langer 1984; Díaz-Morales, 2006) although for diagnostic purposes we will consider it a one-dimensional variable. The future time perspective would be the students' tendency to select the future timeframe when making academic decisions about their professional future (Honora \& Freeman, 2001) and decisions about choosing future studies, conditioned by parent-family environments and influenced by other variables such as motivation (Lens, 2001) and the orientation toward social and learning goals (De la Fuente Arias, 2002).

Self-regulated learning refers to a goal-oriented, proactive process. At the risk of simplifying, and taking into account that the self-regulated learning components are reciprocally determined, we include four key propositions to explain the sense and direction of the relationships among the components of the self-regulated learning perspective, reasons supporting this study:

a) The use of cognitive regulation strategies significantly contributes to efficient learning and academic success (Zimmerman, 2000; Zimmerman \& Schunk, 2011);

b) Self-regulated students use meta-cognitive and cognitive strategies more often when they feel motivated and committed to the activity (Vansteenkiste, Simons, Lens, Shenldon \& Deci, 2004);

c) Motivation and commitment to the activity depend on adopting a certain goal achievement approach (Elliot, 1999). Unlike avoidance goals, approach goals (performance and mastery) contribute to higher levels of motivation and internal regulation.

d) Two key components that explain the adoption of approach goals are selfefficacy beliefs and the degree of usefulness the students assign to the learning activities in an educational setting, with regard to their future goals (Husman \& Lens, 1999; Wigfield \& Eccles, 2000).

The study of constructive learning processes has mainly been carried out from two perspectives (Gutiérrez-Braojos, 2015): students' learning patterns (Vermunt, 1998) and self-regulated learning (Pintrich, 2004). The learning pattern approach emphasizes the role of conceptions about learning, whereas the self-regulated learning approach emphasizes the role motivation plays in the self-regulated process (Zimmerman \& Schunk, 2009). Taking these aspects into account, different studies have analyzed the relationship between self-regulated learning and the time perspective (Peetsma, Has- 
cher, Van der Ven y Roede, 2005; Shell \& Husman, 2001; Horstmanshof \& Zimitat, 2007; De Bilde, Vansteenkiste \& Lens, 2011). The results coincide in affirming that only students oriented toward the future are self-regulated students, although a large number of these studies have not analyzed other possible time patterns and their modulator effect on self-regulated learning (Gutiérrez-Braojos et al. , 2014).

As in the personal positioning when faced with any educational reality, people are influenced by time, even when they are not aware of it. The perspective one has of time as a mediator element becomes a screen between the person and the reality. Thus the self-comprehension of his/her timeframes allows each person to codify, organize, and record past and present experiences, and construct new goals, expectations, and scenarios (Zimbardo \& Boyd, 1999).

One aspect to highlight in relation to both constructs, the time perspective and self-regulated learning, is the essential importance shown by the construction of the cognitive functions, as the cognitive representation derived from them allows the student to keep in mind the events that have already occurred or that are coming, regardless of their current and real presence (Nuttin, 1980). The future time perspective implies the mental representation of the future in the present, and it includes the motivational goals or objectives, as well as their placement in time. These motivational objectives make up the content of the future time perspective, and their time placement defines the time when these goals will be achieved in the short, medium, or long term (González \& Daura, 2012).

In the same way, Zimmerman (2000) considers that the capacity to self-regulate involves the generation of thoughts and feelings and the planning of the necessary actions to reach personal goals. He also describes self-regulation as a cyclical process in which the previous performance and efficacy or self-efficacy beliefs provide feedback about the learning activities carried out, readjusting them accordingly.

According to these contributions, students with an extensive future time perspective produce a high number of goals that can only be achieved in the distant future, whereas those with a less extensive time perspective have more short- or medium-term goals (Lens \& Moreas, 1994; Nuttin, 1985). In synthesis, the student with an extended future time perspective who internally regulates his/her learning, establishes valuable self-realization goals, and freely makes a commitment to them, will be highly motivated and have a realistic personality that is coherent with his/ her self (González \& Daura, 2012).

\section{Time perspective and learning by gender}

Another proposal in this study is to identify whether differences in positioning between women and men with regard to motivational-cognitive variables are related to their learning processes, or whether the responses to certain academic demands are determined by the presence of biases or by the individual capabilities displayed.

Regarding the measurement of gender differences in learning strategies and styles, we highlight the study by Cano (2000), which uses the L.A.S.S.I Learning and study 
strategies inventory by Weinstein (1987) and the normative version of the latter, the Learning Styles Questionnaire, (Marshall \& Merrit, 1986), along with others, such as the A.S.I. Approaches to Studying Inventory (Entwistle, Hanley \& Hounsell, 1979) and the I.L.P. Inventory of Learning Processes, by Schmeck, Ribich, \& Ramanaiah (1977). This study finds significant gender differences in these factors in the science, social sciences, and humanities degrees, weighing the explanatory importance of the differences in calculating the effect size (Cohen, 1988). The authors observe gender differences in the use of strategies in each of the degrees studied, not based as much on the type of degree, but rather on the presence or absence of the use of strategies. The female students obtain better positions than the males on intrinsic motivation, attitude, and interest in their studies. There are also differences in their support strategies, although these latter differences are associated with the context and type of degree, as they appear in some but not in others. However, regarding the learning style, whereas the male students manifest a deeper processing of the information (significant learning, data contrast...), the female students stand out in methodic study (with organization and study support techniques). Greater study anxiety is also identified in the female students than in the male students, regardless of the degree studied.

With regard to gender and the time dimension, the results are scarce (Zaleski, 1994). In general, the majority of the studies on the time orientation find no gender differences (Bouffard et al., 1994; Lapierre, Boufard \& Bastin, 1997). However, Zimbardo and Boyd (1999) find that female university students are more oriented toward the positive past and the future.

The study by Cerezo and Casanova (2004) focuses on the search for differences in factors such as the motivational orientation, high school students' causal attributions in situations of academic success or failure, self-concept, and the learning strategies used. They observed significant differences in the causal attributions, motivation, and learning strategies: the female students consider failure to be due more to internal factors (low level on some skills), whereas the male students attribute it to external factors (luck, teachers); both groups coincide in attributing success to effort. Regarding motivation, differences only appear on extrinsic motivation: the male students, compared to the female students, tend to look for positive external opinions about their competence, and they avoid negative ones. The female students make greater use of information processing strategies and self-evaluation than the males.

Focusing on the motivational variables as determinants in the development of selfregulation of learning, Suarez, Anaya and Gómez (2004) investigate the relationships established, depending on gender, with regard to: i) motivational and self-regulated learning variables and ii) variables that strategically provide students with greater involvement in their learning (desire, effort, commitment) and facilitate orientation toward their academic goals. The results show differences in the female students' manifestations about the three types of self-regulation strategies. The female students show a greater degree of control and regulation in the development of their learning, both cognitive and social, linked to their studies.

The aim of our study is to quantify the influence of gender and the future time perspective on self-regulated learning. 


\section{Method}

\section{Objectives}

Three knowledge objectives were established related to the time orientation, achievement goals, regulation strategies, academic achievement, and gender of the participants.

Objective 1. To test a theoretical model of academic achievement modulated by self-regulated learning, in which the following hypotheses are proposed, based on most of the literature reviewed (Figure 1).

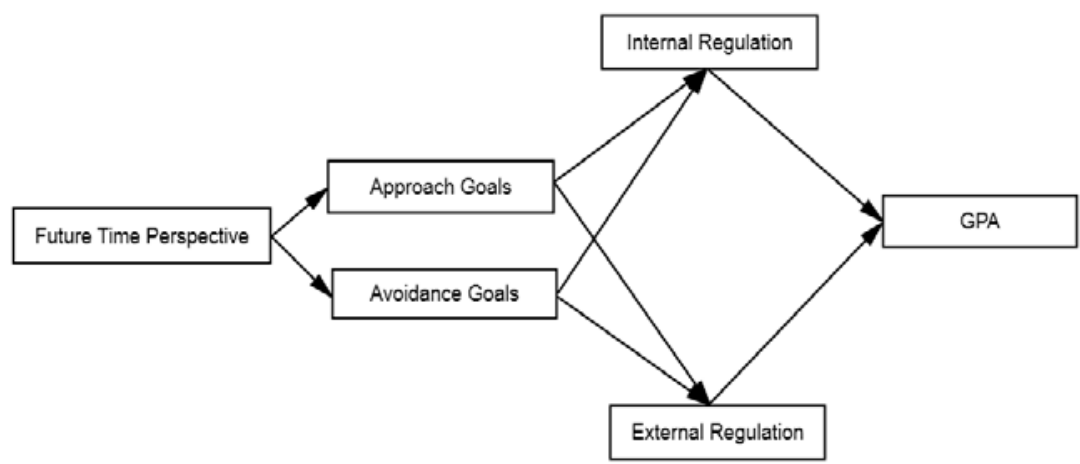

Figure 1. Theoretical Model of self-regulated learning and GPA in the degree

- The future time orientation variable positively contributes to approach goals, internal regulation strategies, and the mean grade point average in the bachelor's degree, but it contributes negatively to avoidance goals and external regulation strategies.

- The approach goals variable contributes positively to the internal regulation strategies and the GPA in the degree, but it contributes negatively to external regulation strategies.

- The avoidance goals variable contributes negatively to the internal regulation strategies and the GPA in the degree, but it contributes positively to the external regulation strategies.

- The internal regulation strategies variable contributes positively to the GPA in the degree.

- The external regulation strategies variable contributes negatively to the GPA in the degree.

Objective 2. Analyze statistically significant differences between the means on selfregulated learning and the time patterns depending on the gender of the participants. In this objective, we formulate the following hypothesis:

- There are differences in the means on these variables depending on the gender. 
Objective 3. Identify profiles of self-regulated learning toward academic achievement taking the gender variable as the grouping factor, which makes it possible to study types of learners by gender. This objective contains three hypotheses:

- There are different profiles of students, regardless of the gender.

- The student profiles that are found to be more self-regulating will obtain better grades on academic achievement, regardless of their gender.

- The profiles between the two groups (males vs. females) present similar characteristics in their configurations.

\section{Population and Sample}

In this study, the participants were 192 university students from the branch of social and legal sciences. They had a mean age of 23.24 years $(S D=3.71)$, and $50 \%$ were women.

\section{Information collection instruments and application procedure}

The battery was composed of three instruments and one question asking about the GPA in the degree so far. The battery was applied in the presence of the teacher. First, the response procedure for the battery of instruments was presented and explained. Later, the students were given a booklet with the instructions, examples of the response procedure, and the different subscales.

The participants responded to all the questionnaires on a 5-point Likert scale, where the " 1 " indicated "not very characteristic of $\mathrm{me}^{\text {"; }}$ and " 5 " represented "quite characteristic of me".

I) Future time orientation subscale by Zimbardo.

To measure students' attitudes about the future time orientation, the future subscale from the time perspective inventory by Zimbardo was applied (ZTPI, Zimbardo \& Boyd, 1999). The subscale is composed of 13 items. Previous studies have found adequate reliability values for this subscale (Díaz-Morales, 2006; Horstmanshof \& Zimitat, 2007; Zimbardo, Keough \& Boyd, 1997). In our study, an acceptable Cronbach's alpha was found $(\alpha=.91)$.

II) 2x2 Achievement Goal scale by Elliot and McGregor (2001).

The scale is made up of 12 items that can be grouped in two factors according to the valence: Approach goals (mastery and performance, 6 items) and avoidance goals (mastery and performance, 6 items). The structure validity and reliability of the subscales has been acceptable in numerous studies (Elliot, 1999; SalmerónPérez, Gutiérrez-Braojos, Rodríguez-Fernández \& Salmerón-Vílchez, 2011). In the present study, the Cronbach alpha values were both good: approach goals $(\alpha=.87)$ avoidance goals $(\alpha=.96)$.

iii) Regulation of learning subscale by Vermunt (1998).

The regulation scale of the ILS (ILS, Vermunt, 1998, adapted by Martinez-Fernández et al., 2009) is composed of 28 items grouped in three factors: self-regulation 
strategies (11 items); external regulation strategies (11 items); lack of regulation (6 items). The structure validity and reliability of the scale and subscale have been acceptable in numerous studies (Vermunt. 1998; Salmerón-Pérez et al., 2011). In the present study, the Cronbach alpha values were good: self-regulation $\alpha=.94$; external regulation $(\alpha=.91)$, and lack of regulation $(\alpha=.90)$.

In addition, to find out the mean grade in the degree, students were asked to report their GPA until that time, using a range of values from 0 to 10 points (see Shell and Husman, 2001, for similar measures of the GPA in a degree).

\section{Analytical procedure}

The three sequenced objectives required different analytical approaches:

- To achieve the first objective, a path analysis was applied with the bootstrap (10.000 samples) sampling procedure. The model was evaluated using different indexes (Bentler, 1990): i) The chi-square of the estimated model, where nonsignificant associated $p$-values indicate a good fit; ii) Root Mean Square Error of Approximation (RMSEA), where values less than ".08" indicate an acceptable fit, and values below .05 indicate a good fit; iii)Goodness of Fit Index (GFI), its adjusted measure, (AGFI), the Tucker and Lewis Index (TLI); and the Comparative Fit Index (CFI), indices where values close to " 1 " show a good fit, with recommended threshold values superior to.90 (Byrne, 2010). Moreover, given that none of the variables presented a normal distribution according to Kolmogorov-Smirnov, the Bollen-Stine resampling procedure was applied to obtain a p-value for the global fit of the model's hypotheses and correct the lack of normality (Bollen \& Stine, 1992). Finally, we analyzed the direct, indirect, and total effects on the endogenous variables and their significance using the bootstrap resampling procedure (Hayes, 2013).

- To achieve the second objective, the Mann Whitney U-Wilcoxentest was applied, and the effect size was calculated in order to compare the variables tested in the theoretical model of self-regulated learning, according to the attributive gender variable.

- And finally, to achieve the third objective, two cluster analyses were performed through K-means, one for each gender-based sample.

\section{Results}

\section{Analysis of the explanatory model of the GPA based on the self-regulated learning variables}

The academic achievement model explained by self-regulated learning (Figure 2) shows a good fit to the data (Table 1). The p-values are above ".05". The RMSEA value is below ". 8 "; and the RMR value is close to " 0 ". Likewise, the GFI, AGFI, TLI, and CFY values are above ".9". 
Table 1

Fit indexes of the theoretical model tested

\begin{tabular}{ccccccccccc}
\hline$\chi^{2}$ & DF. & $\begin{array}{c}\text { CMIN/ } \\
\text { DF }\end{array}$ & $P$ & $p$ Bollen-Stine & $\begin{array}{c}\text { RM- } \\
\text { SEA }\end{array}$ & RMR & GFI & AGFI & TLI & CFI \\
\hline 14.033 & 7 & 2.005 & .051 & .074 & .73 & .049 & .977 & .932 & .945 & .974 \\
\hline
\end{tabular}

The results of the direct, indirect, and total effects are presented in table 2. These results indicate that the future time orientation $(b=.188, p<.001)$, approach goals $(b$ $=.271, p<.001)$, avoidance goals $(b=.105, p<.009)$, external regulation strategies $(b=$ $.233, p<.002)$, and internal regulation strategies $(b=.5, p<.001)$ present a positive load on the GPA in the degree. Furthermore, a positive and significant relationship was also found between avoidance goals and the lack of regulation variable $(b=.62, p=$ .004). However, the variables external regulation strategies and avoidance goals did not have significant effects on the GPA. On the other hand, the future time orientation $(b=.318, p<.001)$ and approach goals $(b=.472, p<.001)$ are the only variables that present a positive load with the internal regulation strategies, whereas the future time orientation $(b=.123, p<.021)$, avoidance goals $(b=.334, p<.001)$, and approach goals $(b$ $=.153, p<.023$ ) present a positive load on external regulation. Finally, the future time orientation presents a positive effect on the approach goals $(b=.667, p<.001)$, but the effect of the future orientation on avoidance goals is not significant.

Table 2

Direct, indirect, and total effects of the model of Self-regulated learning and academic achievement

\begin{tabular}{lccc}
\hline \multicolumn{1}{c}{ Variables in the Theoretical Model } & Total E. & Direct E. & Indirect effects \\
\hline On Mean GPA & & & \\
\hline Internal Regulation & .5 & .5 & - \\
& $(* * *)$ & $(* * *)$ & - \\
\hline External Regulation & .233 & .233 & \\
\hline Approach Goals & $(.002)$ & $(.002)$ & .271 \\
& .271 & - & $\left({ }^{* *}\right)$ \\
\hline Avoidance Goals & $(* *)$ & & .105 \\
& .105 & - & $.009)$ \\
\hline Future Time Orientation & $(.009)$ & & .188 \\
& .188 & - & $\left({ }^{* * *}\right)$ \\
\hline On Internal Regulation & $(* * *)$ & & - \\
\hline Approach Goals & & & .472 \\
\hline
\end{tabular}




\begin{tabular}{lccc}
\hline Avoidance Goals & .055 & .055 & - \\
& $(.393)$ & $(.393)$ & .318 \\
\hline Future Time Orientation & .318 & - & $\left({ }^{* *}\right)$ \\
\hline On External Regulation & & & \\
\hline Approach goals & & & - \\
& .153 & .153 & - \\
\hline Avoidance goals & $(.023)$ & $(.023)$ & .123 \\
& .334 & .334 & - \\
\hline Future time orientation & $(* *)$ & $(* *)$ & - \\
& .123 & & - \\
\hline On Approach Goals & $(.021)$ & & \\
\hline Future time orientation & & .667 & \\
& .667 & $(* * *)$ & \\
\hline On Avoidance goals & $(* * *)$ & .064 & \\
\hline Future time orientation & .064 & & \\
\hline *** Indicates that the $p$-value is $\leq .001$ & & & \\
\hline
\end{tabular}

The results of the model (Figure 2, Table 2) show the importance of the future orientation, the approach goals, and the students' regulation as a determinant factor in their academic success. In addition, the results show a positive and significant relationship between the future time orientation, the approach goals, and the external regulation strategies, and the GPA in the degree. However, in the latter case, the positive load of the relationship among the variables is much lower. Based on these results, we can capture the presence of different profiles of students in the sample.

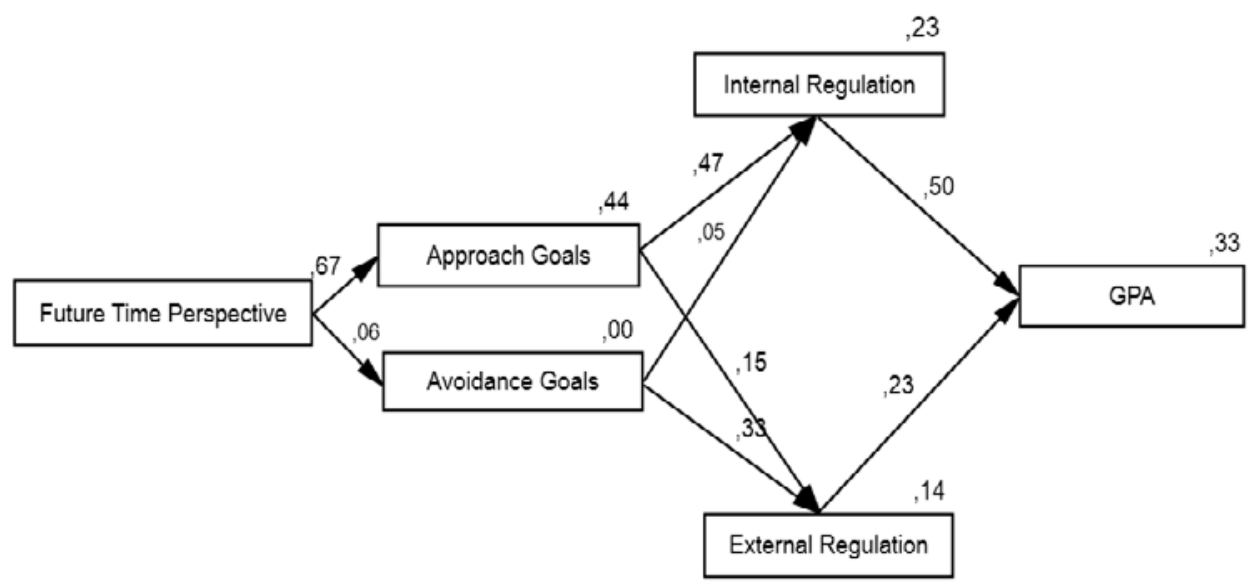

Figure 2. Theoretical Model: Effects of self-regulated learning on the GPA in the degree 


\section{Differences in self-regulated learning based on Gender}

The second objective of this study was to analyze whether there are significant differences in the variables involved in self-regulated learning depending on the gender of the participants. To do so, given that the variables do not present a normal distribution, the Mann-Whitney-Wilcoxen $U$ test was applied. The results show significant differences in favor of the female gender on the following variables: approach goals $(Z=2.68, p=$ $.007)$, internal regulation $(Z=4.45, p<.001)$, and GPA $(Z=2.68, p<.037)$ (Table 3$)$. In all three cases, the effect sizes are in a range of values that indicate a moderate effect size, with the largest being the internal regulation variable $(g=.698)$.

Table 3

Between groups comparison applying the Mann Whitney-Wilcoxon U test

\begin{tabular}{|c|c|c|c|c|c|c|c|c|c|c|c|c|c|}
\hline $\begin{array}{l}\text { Dependent } \\
\text { Variables }\end{array}$ & \multicolumn{6}{|c|}{ Man } & \multicolumn{7}{|c|}{ Woman } \\
\hline FTO & 2.91 & .78 & 2.76 & 88.81 & 3.14 & .82 & 3.15 & 104.19 & 3869.5 & 8525.5 & -1.91 & .055 & -.286 \\
\hline $\mathrm{AvG}$ & 2.69 & 1.3 & 2.5 & 95.3 & 2,79 & 1.40 & 2.33 & 97.7 & 4493 & 9149 & -.3 & .764 & -.073 \\
\hline ApG & 3.2 & 1.04 & 3.16 & 85.77 & 3.6 & 1.03 & 3.83 & 107.23 & 3577.5 & 8233.5 & -2.68 & .007 & -.384 \\
\hline ER & 3.59 & .73 & 3.72 & 92.81 & 3.67 & .78 & 3.86 & 100.19 & 4253.5 & 8909.5 & -.92 & .357 & -.105 \\
\hline IR & 2.68 & 1.07 & 2.36 & 78.65 & 3.37 & .89 & 3.63 & 114.35 & 2894 & 7550 & -4.45 & .000 & -.698 \\
\hline GPA & 6.85 & .95 & 7 & 88.14 & 7.18 & .91 & 7 & 104.86 & 3805 & 8461 & -2.09 & .037 & .353 \\
\hline
\end{tabular}

Note: OFT, future time orientation. AvG, avoidance goals. ApG, approach goals. ER, regulation externa. IR, Internal Regulation, GPA, mean grade

\section{Self-regulated learning profiles by gender}

Furthermore, in this study we decided to analyze students' profiles according to gender, although this was not an objective of the initial study plan. The results obtained in the path analysis led us to propose the hypothesis of profiles of students with academic success with significant differences among them on the self-regulated learning variables. The results obtained show that, regardless of the gender, these profiles exist. Next, we will describe them.

The results obtained for both sexes are similar with regard to self-regulated learning and academic success (Tables 2 and 3):

- One of the profiles ( $n=34$ in the case of men; $n=37$ in the case of women) with academic success shows a group of students who are strongly oriented toward the future, experience approach achievement goals, and apply internal and external regulation strategies. 
- A second profile with academic success $(n=27$ in the case of the men; $n=26$ in the case of the women) presents a moderated future orientation, a combination of avoidance and approach goals, and a combination of external and internal regulation strategies.

- Finally, the third profile with considerably less academic success than the rest ( $n=35$ in the case of the men; $n=33$, in the case of the women) shows a relative lack of future orientation, approach goals, avoidance goals, and internal regulation, and receive higher scores on external regulation.

Table 4

Cluster K-Means Analysis: profiles in the group of male students

\begin{tabular}{lccccccccc}
\hline Variables & \multicolumn{2}{c}{$\begin{array}{c}\text { Cluster } 1 \\
(n=35)\end{array}$} & \multicolumn{2}{c}{$\begin{array}{c}\text { Cluster } 2 \\
(n=27)\end{array}$} & \multicolumn{2}{c}{$\begin{array}{c}\text { Cluster } 3 \\
(n=34)\end{array}$} & \multicolumn{2}{c}{ Associated values } \\
\hline & Mean & SD & Mean & SD & Mean & SD & $F$ & $p$ & $\eta^{2}$ \\
\hline FTO & 2.44 & .63 & 2.90 & .79 & 3.42 & .59 & 18.24 & $* * *$ & .28 \\
\hline AvG & 2.33 & .92 & 4.28 & .86 & 1.81 & .64 & 73.84 & $* * *$ & .61 \\
\hline ApG & 2.35 & .83 & 3.36 & .96 & 3.96 & .55 & 36.24 & $* * *$ & .44 \\
\hline ER & 3.24 & .69 & 4.03 & .59 & 3.63 & .69 & 10.68 & $* * *$ & .19 \\
\hline IR & 1.86 & .57 & 2.85 & .88 & 3.41 & 1.04 & 29.34 & $* * *$ & .39 \\
\hline GPA & 6.10 & .69 & 7.21 & .74 & 7.36 & .84 & 26.98 & $* * *$ & .37 \\
\hline
\end{tabular}

Note: FTO, future time orientation. AvG, avoidance goals. ApG, approach goals. ER, External regulation. IR, Internal Regulation. GPA, mean grade

Table 5

Cluster K-Means Analysis: profiles in the group of female students

\begin{tabular}{lccccccccc}
\hline Variables & \multicolumn{2}{c}{$\begin{array}{c}\text { Cluster } 1 \\
(n=33)\end{array}$} & \multicolumn{2}{c}{$\begin{array}{c}\text { Cluster } 2 \\
(n=26)\end{array}$} & \multicolumn{2}{c}{$\begin{array}{c}\text { Cluster } 3 \\
(n=37)\end{array}$} \\
\hline & Mean & SD & Mean & SD & Mean & SD & $F$ & $p$ & $\eta^{2}$ \\
\hline FTO & 2.72 & .68 & 3.48 & .70 & 3.29 & .86 & 8.18 & .001 & .15 \\
\hline AvG & 2.11 & .85 & 4.82 & .36 & 1.96 & .61 & 170.47 & $* * *$ & .79 \\
\hline ApG & 2.71 & .99 & 4.05 & .82 & 4.07 & .59 & 30.02 & $* * *$ & .39 \\
\hline ER & 3.12 & .82 & 4.12 & .51 & 3.83 & .62 & 18.04 & $* * *$ & 28 \\
\hline IR & 2.48 & .66 & 3.65 & .64 & 3.97 & .54 & 54.25 & $* * *$ & .54 \\
\hline GPA & 6.43 & .61 & 7.15 & .70 & 7.86 & .73 & 38.2 & $* * *$ & .45 \\
\hline
\end{tabular}

Note: FTO, future time orientation. AvG, avoidance goals. ApG, approach goals. ER, External regulation. IR, Internal Regulation. GPA, mean grade 


\section{Discussion and conclusions}

To reach the first objective of this study, we tested a theoretical model of academic achievement through self-regulated learning. The analysis showed that the theoretical model presents a good fit, although the hypotheses were partially confirmed; not all of the relationships and valences found were those proposed in the hypotheses based on almost the entire body of literature reviewed.

Specifically, the results support previous studies that emphasize the importance of the future orientation, approach goals, and students' regulation as a determinant factor in academic success (Bilde et al., 2011; Gutiérrez-Braojos et al., 2014; Horstmanshof \& Zimitat, 2007; Husman \& Lens, 1999; Wigfield \& Eccles, 2000; Zimmerman \& Schunk, 2011).

However, in contrast to the hypotheses established, a significant and positive relationship was also found between the future time orientation, approach goals, and external regulation strategies, and a lack of relationship between the future time orientation and avoidance goals confirmed the findings of Gutiérrez-Braojos (2015). In addition, unlike in the hypotheses, a significant and positive relationship was found between the avoidance goals and external regulation and the GPA in the degree, contradicting all of the studies reviewed. Therefore, these findings could indicate that there are students who present opposing goals (avoidance and approach). This might be due to specific characteristics associated with each domain and each subject. Students in the same degree participate in different subjects and can adopt different goals and regulation strategies for each. When asked about goals and the use of regulation strategies, students who face learning experiences in a qualitatively different way, depending on their interest in the topics, could present a learner profile with these apparent contradictions. In any case, these results led us to question the model's coverage and apply a Cluster analysis based on the "Gender" of the students if there were significant differences between the two sexes.

In a second study objective, we analyzed whether the self-regulated learning variables tested in the theoretical model are relevant in explaining academic achievement based on the gender. The results show that the women in the sample present significantly higher scores than the men on key variables in academic achievement, such as self-regulated learning, although the effect size was not large. These results confirm those from previous studies (Cano, 2000; Cerezo \& Casanova, 2004; Suarez et al., 2004).

Once differences by sex had been determined, and in order to obtain more detailed knowledge about the students in each group organized by the attributive variable "Gender" and analyze possible different gender profiles, a k means Cluster analysis was conducted, obtaining three profiles in each group. The results showed that, for both the men and the women, a pattern is observed that is similar to the one referred to as proactive by Gutiérrez-Braojos et al. (2014), except that the students also use external regulation strategies, as found in Gutiérrez Braojos, (2015). These students have the future time orientation, low scores on avoidance goals, and high scores on approach goals, internal regulation strategies, external regulation strategies, and GPA. A second profile of students is quite similar to the previous one, but, in addition, they state that they apply both types of achievement goals (avoidance and approach). 
Therefore, there are students who follow both goals and both strategies, and have a future orientation and academic success. Finally, in both groups, there is a profile of students with low scores on the future orientation, approach goals and avoidance goals, regulation strategies, and academic achievement, and they reveal that they are mainly externally regulated.

Therefore, the gender differences are only quantitative. In both groups, the characteristics of the learners' profiles are somewhat similar, with no noteworthy differences observed between the genders. Thus, we can accept the presence of three profiles in the whole sample.

Thus, regardless of the group, our results allow us to conclude that the avoidance goals and external regulation strategies can lead to success in academic achievement, as long as they are accompanied by the variables future orientation and internal regulation, and approach goals. In other words, these latter variables are indispensable in explaining academic achievement. Another conclusion is that the students can present both types of goals (approach/avoidance) and both types of strategies (internal and external) from a future-oriented pattern and reach good academic results.

One of the limitations of this study is the sample size, which was acceptable, but the identification of three groups meant a noteworthy decrease in the number of observations for each model in the multi-group analysis. Therefore, these results should be interpreted with this sample composition difference in mind; we suggest randomly selecting a proportional sample in terms of gender, along with a larger number of observations in order to study the moderator effect of the time patterns based on this variable.

\section{References}

Bentler, P. M. (1990). Comparative fit indexes in structural models. Psychological Bulletin, 107, 238-246.

Bollen, K.A., \& Stine, R.A. (1992). Bootstrapping goodness-of-fit measures in structural equation models. Sociological Methods and Research, 21, 205-229.

Bouffard, L., Bastin, E., \& Lapierre, S. (1994). The personal future in old age. In Z. Zaleski (Ed.). Psychology of future orientation. Lublin, Poland: Lublin University Press.

Byrne, B.M. (2010). Structural equation modeling with AMOS. New York, NY: Routledge.

Cano, F. (2000). Diferencias de género en estrategias y estilos de aprendizaje. Psicothema, $12,360-367$.

Cerezo, M.T. \& Casanova, F. (2004). Diferencias de género en la motivación académica de los alumnos de Educación Secundaria Obligatoria. Revista Electrónica de Investigación Psicoeducativa, 2(1), 97-112.

Cohen, J. (1988). Statistical power analysis for behavioral sciences ( $2^{\underline{0}}$ ed.). Hillsdale, NJ: Erlbaum.

Daltrey, M., \& Langer, P. (1984). Development and evaluation of a measure of future time perspective. Perceptual and Motor Skills, 58, 719-725.

De Bilde, J., Vansteenkiste, M., \& Lens, W. (2011). Understanding the association between future time perspective and self-regulated learning through the lens of self-determination theory. Learning and Instruction, 21, 332-344. 
De la Fuente Arias, J. (2002). Perspectivas recientes en el estudio de la motivación: la Teoría de la Orientación a Meta. Escritos de Psicología 6, 72-84.

Díaz-Morales, J. F. (2006). Estructura factorial y fiabilidad del Inventario de Perspectiva Temporal de Zimbardo. Psicothema, 18(3), 565-571.

Elliot, A. J., \& McGregor, H. A. (2001). A $2 \times 2$ achievement goal framework. Journal of Personality and Social Psychology, 80, 501-519.

Elliot, A.J. (1999). Approach and avoidance motivation and achievement goals. Educational Psychologist, 34, 169-189.

Entwistle, N. J., Hanley, M., \& Hounsell, D. J. (1979). Identifying distinctive approaches to studying. Higher Education, 8, 365-380.

Fraisse, P. (1967). Psychologie du temps ( $2^{\mathrm{a}}$ edición). Paris: PUF

Gjesme, T. (1983). On the concept of future time orientation: Considerations of some functions' and measurements' implications. International Journal of Psychology, 18, 443-461.

González, M.L., \& Daura, F.T. (2012). El aprendizaje auto-regulado y su vinculación con la perspectiva de futuro. Revista de orientación Educacional, 26(50), 47-72.

Gutiérrez-Braojos, C. (2015). Future time orientation and learning conceptions: effects on metacognitive strategies, self-efficacy beliefs, study effort and academic achievement. Educational Psychology, 35(2), 192-212. doi. org/10.1080/01443410.2013.858101

Gutiérrez-Braojos, C.; Salmerón-Pérez, H. \& Muñoz-Cantero, J.M. (2014). El efecto modulador de los patrones temporales sobre el logro en el aprendizaje autorregulado. Revista de Psicodidáctica, 19(2), 267-287. doi. 10.1387/RevPsicodidact.10066

Hayes, A.F. (2013). Introduction to mediation, moderation, and conditional process analysis: A regression-based approach. London: The Guilford Press

Holman, E.A., \& Silver, R.C. (1998). Getting "stuck" in the past: temporal orientation and coping trauma. Journal of Personality and Social Psychology, 74(5), 1146-1163.

Honora, D., \& Freeman, J. (2001). Future time perspective as a correlate to academic achievement and school membership among urban African American adolescents. Adolescence, 42(167), 525-538.

Horstmanshof, L., \& Zimitat, C. (2007). Future time orientation predicts academic engagement among first-year university students. British Journal of Educational Psychology, 77(3), 703-718. doi. 10.1348/000709906X160778

Husman, J., \& Lens, W. (1999). The role of the Future in Student Motivation. Educational Psychologist, 34, 113-125.

James, W. (1890). The principles of psychology. New York: Holt.

Lapierre, S., Bouffard, L., \& Bastin, E. (1997). Personal goals and subjective well-being in later life. International Journal of Aging and Human Development, 45, 287-303.

Lens, W., \& Moreas, M. (1994). Future time perspective: individual and societal approach. In Z. Zaleski (Ed.), Psychology of future orientation. Polonia: Towarzystwo Naukowe KUL.

Lens, W. (1986). Future time perspective: A cognitive-motivational concept. In D.R. Brown \& J. Veroff (Eds.), Frontiers of motivational psychology (pp. 173-190). New York: Springer-Verlag.

Lens, W. (2001). How to combine intrinsic task-motivation with the motivational effects of the instrumentality of present tasks for future goals. In A. Efklides, J. Kuhhl \& R.M, Sorrentino (Eds.). Trends and prospects in motivation research (pp. 23-36), New York, NY: Kluver. 
Lewin, K. (1942). Time perspective and morale. In G. Watson (eds.): Civilian morale. Boston Houghton Mifflin

Marshall, J.C., \& Merrit, S.L. (1986). Reliability and construct validity of the learning style questionnaire. Educational and Psychological Measurement, 46, 257-262.

Martínez-Fernández, J. R., García-Ravidá, L., González-Veláquez, L., Gutiérrez-Braojos, C., Poggioli, L.,Ramírez-Otálvaro, P., \& Tellería,M. B. (2009). Learning pattern inventory (in Spanish). Internal documentofthe PAFIU research team. Barcelona: Universitat Autònoma de Barcelona.

Nuttin, J. (1980). Motivation et perspective d'avenir. Belgica: Presses Universitaires.

Nuttin, J. (1985). Future time perspective and motivation: theory and research method. Hillsdale, NJ: Erlbaum.

Peetsma, T., Hascher, T., Van der Veen, I., \& Roede, E. (2005). Relations between adolescents' self-evaluations, time perspectives, motivation for school and their achievement in different countries and at different ages. European Journal of Psychology of Education, 20, 209-225.

Peetsma, T.T.D. (2000). Future time perspective as a predictor of school investment. Scandinavian Journal of Educational Research, 44, 179-194.

Pintrich, P. R. (2004). A conceptual framework for assessing motivation and selfregulated learning in college students. Educational Psychology Review, 16, 385-407.

Roberts, W.A. (2002). Are animals stuck intime? Pschological Bulletin, 128, 473-489.

Roeckelin, J.E. (2000), The concept of time in psychology. Westport, Connecticut: Greenwood Press.

Salmerón Pérez, H., Gutiérrez-Braojos, C., Salmerón-Vílchez, P., \& Rodríguez Fernández, S. (2011). Metas de logro, estrategias de regulación y rendimiento académico en diferentes estudios universitarios. Revista de Investigación Educativa, 29(2), 467-477

Schmeck, R.R., Ribich, F.D., \& Ramanaiah, N. (1977). Development of a self-report inventory for assessing individual differences in learning processes. Applied Psychological Measurement, 1, 413-431.

Shell, D. F., \& Husman, J. (2001). The multivariate dimensionality of personal control and future time perspective in achievement and studying. Contemporary Educational Psychology, 26, 481-506.

Simmons, J. Dewite, S., \& Lens, W. (2000). Wanting to have versus wanting to be: the influence of instrumentality on goal orientation. British Journal of Psychology, 91, 335-351.

Suárez, J. M., Anaya, D., \& Gómez, I. (2004). Diferencias diagnósticas en función del género respecto a la utilización de estrategias autorreguladoras en estudiantes universitarios. Revista de Investigación Educativa, 22(1), 245-258.

Suddendorf, T., \& Corballis, M.C. (1997). Mental time travel and the evolution of the human mind. Genetic, Social and General Psychology Monographs, 123, 133-167.

Thiébaut, E. (1998). La perspective temporelle, un concept a la recherched'une définition opérationnelle. L'Année Psychologie, 98, 101-125.

Trommsdorff, G. (1983). Future orientation and socialization. Journal of International Psychology, 18, 381-406.

Vansteenkiste, M., Simons, J., Lens, W., Sheldon, K. M., \& Deci, E. L. (2004). Motivating learning, performance, and persistence: The synergistic role of intrinsic goals and autonomy-support. Journal of Personality and Social Psychology, 87, 246-260. 
Vermunt, J. (1998). The regulation of constructive learning processes. British Journal of Educational Psychology, 68, 149-171.

Weinstein, C. E. (1987). Learning and study strategies inventory (LASSI). Clearwater, FL: $\mathrm{H} \& \mathrm{H}$ Publishing Company.

Wigfield, A., \& Eccles, J.S. (2000). Expectancy-Value Theory of Achievement Motivation. Contemporary Educational Psychology, 25, 68-81.

Yonge, G.D. (1974). Dimensions of time experiences. Social behavior and personality, 2, 119-124.

Zalesky, Z. (1994). Psychology of future orientation. Poland: Lublin University Press.

Zimbardo, P. G., Keough, K. A., \& Boyd, J. N. (1997). Present time perspective as a predictor of risky driving. Personality and Individual Differences, 23(6), 1007-1023.

Zimbardo, P.G. \& Boyd, N. (1999). Putting time in perspective: a valid, reliable, individual-differences metric. Journal of Personality and Social Psychology, 17(6), 1271-1288.

Zimbardo, P.G., \& Boyd, N. (2008). The time paradox: The new psychology of time that will change your life. London: Rider.

Zimmerman, B. J. (2000). Attaining self-regulation: a social cognitive perspective. In M. Boekaerts, P.R. Pintrich \& M. Zeidner (Ed.). Handbook of self-regulation (pp. 13-38). San Diego: Academic Press.

Zimmerman, B. J., \& Schunk, D. H. (2009). Self-Regulated Learning and Academic Achievement. Theoretical Perspectives ( $2^{\underline{a}}$ ed.). New York: Routledge.

Zimmerman, B. J., \& Schunk, D. H. (2011). Self-regulated learning and performance. In B.J. Zimmerman \& D.H. Schunk (Eds.), Handbook of self-regulation of learning and performance (pp. 1-12). New York: Routledge.

Fecha de recepción: 30 de octubre de 2016

Fecha de revisión: 30 de octubre de 2016

Fecha de aceptación: 08 de marzo de 2017 
